\title{
Asymmetric Diels-Alder Reactions of Chiral Acrylates of Cholic Acid Derivatives
}

\author{
Packiarajan Mathivanan and Uday Maitra* \\ Department of Organic Chemistry, Indian Institute of Science, Bangalore 560 012, India
}

Received June $13,1994^{\circledR}$

\begin{abstract}
New steroid-based chiral auxiliaries 6, 9, and 12 have been synthesized from readily available cholic acid. These new chiral auxiliaries place the reactive and the shielding sites in a 1,5 relationship to each other. Diels-Alder reaction of cyclopentadiene with corresponding acrylate esters $(7,10$, and 13) have been examined. Acrylates 7 and 10 yielded cycloadducts with $29-88 \%$ diastereomeric excess with excellent endo selectivity in the presence of an excess of Lewis acids such as $\mathrm{AlCl}_{3}, \mathrm{BF}_{3} \cdot \mathrm{OEt}_{2}, \mathrm{FeCl}_{3}, \mathrm{SnCl}_{4}, \mathrm{TiCl}_{4}$, and $\mathrm{ZnCl}_{2}$. Treatment of acrylate 7 with cyclopentadiene in the presence of $\mathrm{BF}_{3} \mathrm{OEt}_{2}$ at $-80{ }^{\circ} \mathrm{C}$ gave the endo adduct ( $>99 \%$ ) with $88 \%$ de. Lewis acid catalyzed and uncatalyzed reactions of acrylates $\mathbf{7}$ and 10 with cyclopentadiene yielded cycloadducts with opposite stereochemistry. The chiral auxiliary was recovered in a nondestructive manner only via iodolactonization. Acrylate ester of alcohol 12 did not show any selectivity in either catalyzed and uncatalyzed reactions with cyclopentadiene. The presence of a flat aromatic surface at C-7 of the steroid was found to be essential to effect high diastereoselection.
\end{abstract}

\section{Introduction}

During the past two decades there has been a great deal of interest among chemists to develop new chiral auxiliaries to accomplish synthetic transformations with a high degree of asymmetric induction. ${ }^{1}$ The Diels-Alder reaction has remained one of the most important transformations, playing a vital role in organic synthesis owing to its versatility in constructing in one step as many as four contiguous chiral centers with highly predictable regio- and stereoselectivity. ${ }^{2}$ Recent work in this area has led to the development of new chiral auxiliaries, such as those derived from amino acids, ${ }^{3}$ carbohydrates, ${ }^{4}$ $\alpha$-hydroxy acids, ${ }^{5}$ and terpenoids. ${ }^{6}$ Chiral promotors ${ }^{7}$ and chiral dienes ${ }^{8}$ have also been employed for cycloaddition reactions with varying degrees of success.

In spite of the ready availability in optically pure form, very little attention has been paid toward the use of

* Abstract published in Advance ACS Abstracts, January 1, 1995.

(1) Oppolzer, W. Comprehensive Organic Synthesis: Selectivity, Strategy and Efficiency in Modern Organic Chemistry; Trost, B. M., Ed.; Pergamon Press: Oxford, 1991; $\mathrm{p} 315$.

(2) (a) Paquette, L. A. Asymmetric Synthesis, Vol. 3; Morrison, J. D., Ed.; Academic Press: New York, 1984; p 455, (b) Oppolzer, W. Angew. Chem., Int. Ed. Engl. 1984, 23, 876. (c) Oppolzer, W. Tetrahedron 1987, 43, 1969. (d) Helmchen, G.; Karge, R.; Weetman, J. Modern Synthetic Methods, Vol. 4; Scheffold, R., Ed.; Springer: Heidelberg, 1986; p 262. (e) Corey, E. J. Pure Appl. Chem. 1990, 62, 1209.

(3) Amino acid based chiral dienophiles: (a) Evans, D. A.; Chapman K. T.; Bishaha, J. Tetrahedron Lett. 1984, 25, 4071. (b) Evans, D. A.; Chapman, K. T.; Bisaha, J. J. Am. Chem. Soc. 1988, 110, 1238. (c) Bueno, M. P.; Cativiela, C.; Mayoral, J. A.; Avenoza, A.; Charro, P.; Roy, M. A.; Andres, J. M. Can. J. Chem. 1988, 66, 2626. (d) Bueno, M. P.; Cativiela, C.; Mayoral, J. A. J. Org. Chem. 1991, 56, 6551. (e) Waldmann, H.; Braun, M. Gazz. Chim. Ital. 1991, 121, 277. (f) Waldmann, H. Kontakte (Darmstadt) 1993, 1, 58.

(4) Carbohydrate-derived chiral acrylates: (a) Kunz, H.; Muller, B.; Schanzenbach, D. Angew. Chem., Int. Ed. Engl. 1987, 26, 267. (b) Stahle, W.; Kunz, H. Syn. Lett. 1991, 260. (c) Kunz, H.; Ruck, K. Angew. Chem., Int. Ed. Engl. 1993, 32, 336. (d) Gras, J.-L.; Poncet, A. Nouguier, R. Tetrahedron Lett. 1992, 33, 3323. (e) Nouguier, R.; Gras, J.-L.; Giraud, B.; Virgili, A. Tetrahedron 1992, 48, 6245. (f) Banks, M. R.; Blake, A. J.; Cadogan, J. I. G.; Dawson, I. M.; Gaur, S.; Gosney, I.; Gould, R. O.; Grant, K. J.; Hodgson, K. G. J. Chem. Soc., Chem. Commun. 1993, 1146.

(5) $\alpha$-Hydroxy carboxylic acid derivatives as dienophiles: (a) Poll, T.; Helmchen, G.; Bauer, B. Tetrahedron Lett. 1984, 25, 2191. (b) Poll, T.; Abdel Hady, A. F.; Karge, R.; Linz, G.; Weetman, J.; Helmchen, G. Tetrahedron Lett. 1989, 30, 5595. (c) Helmchen, G.; Abdel Hady, A. F.; Hartmann, H.; Karge, R.; Sartor, K.; Urmann, M. Pure Appl. Chem. $1989,61,409$. steroids as chiral auxiliaries in asymmetric transformations. ${ }^{9}$ We have been interested in the synthesis of a new class of chiral auxiliaries and molecular receptors based on bile acids. In connection with our research program in this direction, we have recently reported the asymmetric synthesis of a Tröger's base analogue using deoxycholic acid as a chiral template, ${ }^{10 \mathrm{a}}$ and additionally, we communicated the synthesis of new chiral auxiliaries derived from inexpensive cholic acid which were used for carrying out Diels-Alder reaction ${ }^{10 \mathrm{~b}}$ and $\alpha$-keto ester reduction. ${ }^{10 c}$ These new chiral auxiliaries place the reactive and the shielding sites in a 1,5 relationship to each other, unlike most of the auxiliaries employed so far which have 1,2 and 1,3 relationships. Here we report in detail the development of this new class of cholic acid based chiral auxiliaries.

Cholic acid was chosen as the precursor because of the presence of three hydroxyl groups oriented on one face of the molecule (Figure 1); additionally, these hydroxyl

(6) Terpene-derived dienophiles: (a) Walborsky, H. M.; Barash, L.; Davis, T. C. J. Org. Chem. 1961, 26, 477; Tetrahedron 1963, 19, 2333. (b) Corey, E. J.; Ensley, H. E. J. Am. Chem. Soc. 1975, 97, 6908. (c) Oppolzer, W.; Chapuis, C.; Bernardinelli, G. Tetrahedron Lett. 1984, 25, 5885. (d) Oppolzer, W.; Chapuis, C.; Dupuis, D.; Guo, M. Helv. Chim. Acta 1985, 68, 2100. (e) Oppolzer, W. Pure Appl. Chem. 1988, 60,$39 ; 1990,62$, 1241. (f) Boeckmann, R. K., Jr.; Nelson, S. G.; Gaul, M. D. J. Am. Chem. Soc. 1992, 114, 2258. (g) Tananka, K.; Uno, H.; Osuga, H.; Suzuki, H. Tetrahedron Asymm. 1993, 4, 629.

(7) Chiral Lewis acid catalysts: (a) Hashimoto, S. I; Komeshima, N.; Koga, K J. Chem. Soc., Chem. Commun. 1978, 437. (b) Seebach, D.; Beck, A. K. Imwinkelried, R.; Roggo, S.; Wonnacott, A. Helv. Chim. Acta 1987, 70, 954. (c) Narakasa, K Synthesis 1991, 1. (d) Hagan, H. B.; Riant, O. Chem. Rev. 1992, 92, 1007. (e) Hawkins, J. M.; Loren, S. Nambu, M. J. Am. Chem. Soc. 1994, 116, 1657.

(8) Chiral dienes: (a) Fischer, M. J.; Hehre, W. H.; Kahn, S. D.; Overman, L. E. J. Am. Chem. Soc. 1988, 110, 4625. (b) Lubineau, A. Queneau, Y. Tetrahedron 1989, 45, 6697. (c) Larsen, D. S.; Stoodley, R. J. J. Chem. Soc., Perkin Trans. I 1890, 1339. (d) Siegel, C.; Thornton, E. R. Tetrahedron Asymm. 1991, 2, 1413. (e) Tripathy, R.; Carroll, P. J.; Thornton, E. R. J. Am. Chem. Soc. 1991, 113, 7630 .

(9) For cholestanol-based chiral auxiliaries, see: (a) Oppolzer, W. Kurth, M.; Reichlin, D.; Chapuis, C.: Mohnhauptand, M.; Moffatt, F. Helv. Chim. Acta 1981, 64, 2802. (b) Huang, D.-L.; Draper, R. W. Tetrahedron Lett. 1994, 35, 661 .

(10) (a) Maitra, U.; Bag, B. G. J. Org. Chem. 1992, 57, 6979. (b) Maitra, U.; Mathivanan, P. J. Chem. Soc. Chem. Commun. 1993, 1469. (c) Maitra, U.; Mathivanan, P. Tetrahedron Asymm. 1994, 5, 1171.

(11) Baker, J. F.; Blickenstaff, R. T. J. Org. Chem. 1975, 40, 1579. 

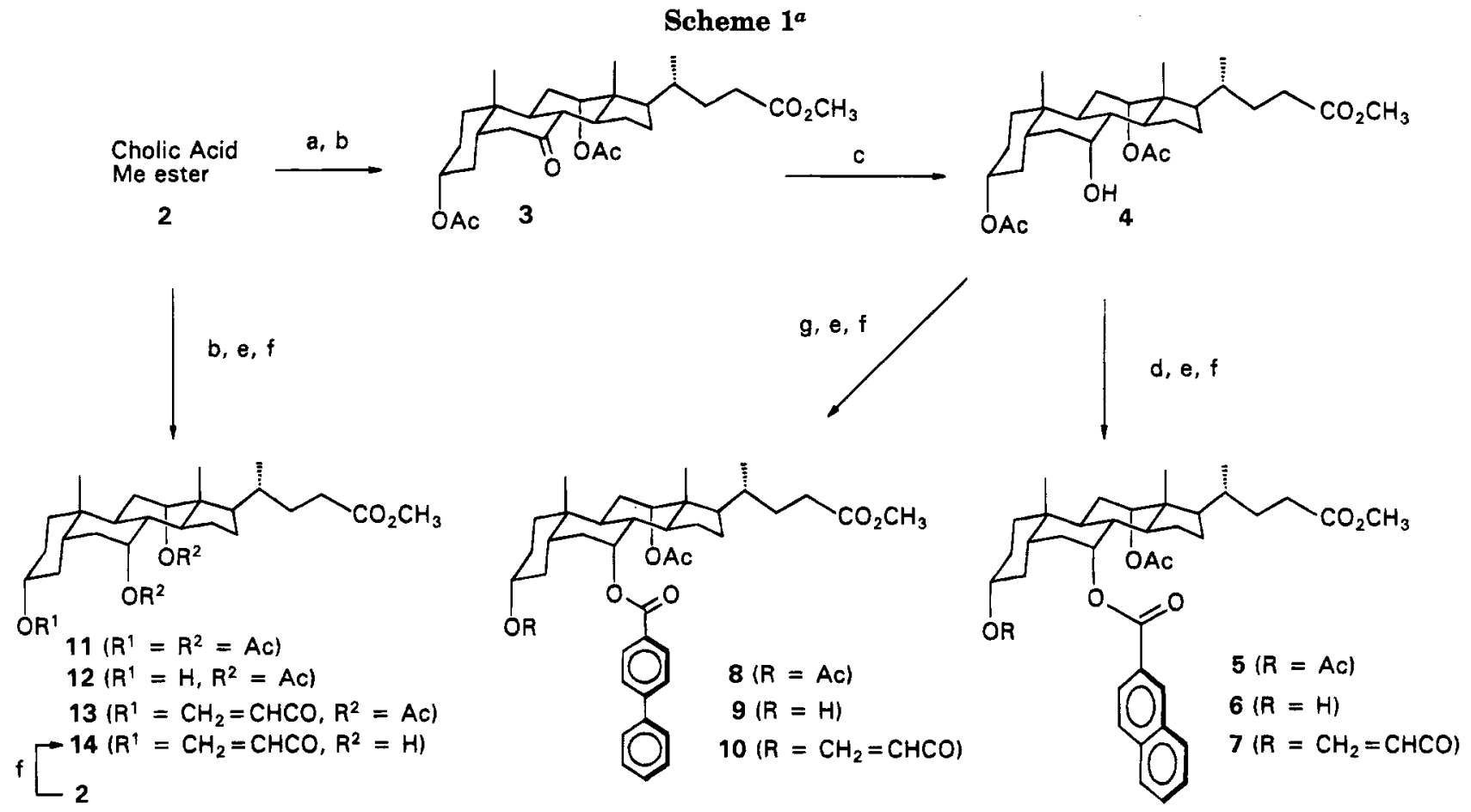

${ }^{a}$ Reaction conditions: (a) NBS, aqueous acetone; (b) $\mathrm{Ac}_{2} \mathrm{O} / \mathrm{Et} \mathrm{t}_{3} \mathrm{~N} / \mathrm{DMAP}$, rt; (c) $\mathrm{NaBH}_{4}, \mathrm{MeOH}, 0{ }^{\circ} \mathrm{C}$; (d) $\mathrm{CaH}, n$-Bun $\mathrm{NI}, 2$-naphthoyl chloride, toluene, reflux; (e) $\mathrm{K}_{2} \mathrm{CO}_{3}, \mathrm{MeOH}$, rt; (f) acryloyl chloride, $\mathrm{Et}_{3} \mathrm{~N}, \mathrm{CH}_{2} \mathrm{Cl}_{2}$; (g) $\mathrm{CaH}_{2}, n-\mathrm{Bu}_{4} \mathrm{NI}$, 4-biphenylcarbonyl chloride, toluene, reflux.

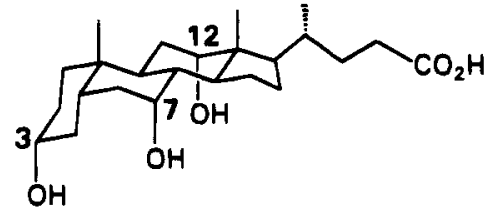

CHOLIC ACID (1)

Figure 1.

groups exhibit differential chemical reactivity. ${ }^{11} \mathrm{We}$ decided to utilize the C-3/C-7 hydroxyl pairs as the reacting and shielding sites, respectively, because of the large reactivity difference exhibited by these two hydroxyl groups and their proximity. It is noteworthy that the hydroxyl groups at C-3 and C-7 are in a 1,5 relationship to each other, and because of the cis $\mathrm{A} / \mathrm{B}$ ring fusion, these two hydroxyl groups are ca. $5 \AA$ (O-3 to O-7) away from each other. ${ }^{12 a}$ The hydroxyl group at C-3 is more reactive toward acylation (and deacylation) than the other two since it is equatorial with respect to ring $\mathrm{A}$. Molecular modeling (DTMM) ${ }^{12 b}$ suggested that the attachment of a large aromatic group at C-7 would result in the shielding of one face of a C-3 substituent. We decided to place naphthalene and biphenyl moieties at C-7 for shielding one face of a prochiral unit suitably attached to C-3.

\section{Results and Discussion}

Chiral acrylate 7 was synthesized from cholic acid in seven steps (overall yield $31 \%$ ) as shown in Scheme 1. In the first step, we protected the C-7 hydroxyl group as

(12) (a) The $O(3)-O(7)$ distance was calculated from the PCMODEL minimized structure of cholic acid. (b) Desktop Molecular Modeller (Version 1.2) program was used to construct molecule 7 from PCMODEL-minimized structure of cholic and 2-naphthoic acids. We thank the Bioinformatics Center of the Indian Institute of Science for providing computational facilities. the corresponding ketone via selective oxidation. Methyl 7-ketocholate (2) was prepared by refluxing cholic acid with methanol in the presence of concd $\mathrm{HCl}$ for $15 \mathrm{~min}$, followed by the selective oxidation of the 7-OH using NBS in acetone/water at room temperature. ${ }^{13}$ Keto ester 2 was acetylated at the C-3 and C-12 hydroxyls with $\mathrm{Ac}_{2} \mathrm{O}$ / $\mathrm{Et}_{3} \mathrm{~N} / \mathrm{DMAP}$ at room temperature to afford diacetoxy keto derivative 3 in $90 \%$ yield. ${ }^{14}$ The reduction of keto ester 3 with $\mathrm{NaBH}_{4}$ in $\mathrm{MeOH}$ at $0{ }^{\circ} \mathrm{C}$ (or with benzyltriethylammonium borohydride in refluxing $\mathrm{CH}_{2} \mathrm{Cl}_{2}$ ) regenerated the required $7 \alpha-\mathrm{OH}$ group, affording alcohol 4 in $85 \%$ yield.

Esterification of the hindered C-7 hydroxyl group in compound 4 with 2-naphthoyl chloride was smoothly carried out under Oppenauer esterification conditions to afford compound $\mathbf{5}$ in $88 \%$ yield. ${ }^{15}$ Treatment of 5 with $\mathrm{K}_{2} \mathrm{CO}_{3}$ in $\mathrm{MeOH}$ at room temperature selectively removed the equatorial $3 \alpha$-acetate to give alcohol 6 in $90 \%$ yield. In an analogous manner, alcohol 9 was synthesized (via 8) by the esterification of alcohol 4 with biphenyl-4carboxylic acid chloride ( $83 \%$ ) followed by deacetylation (96\%) at C-3 as mentioned above. Treatment of alcohols 6 and 9 with acryloyl chloride in the presence of triethylamine in $\mathrm{CH}_{2} \mathrm{Cl}_{2}$ at $0{ }^{\circ} \mathrm{C}$ afforded acrylate esters $7(87 \%)$ and $10(83 \%)$, respectively. In order to find out the effect of the aromatic surface attached at C-7 position, compound 13, with a C-7 acetoxy group, was also prepared. This was synthesized from methyl cholate in three steps: first by the acetylation of methyl cholate with $\mathrm{Ac}_{2} \mathrm{O} / \mathrm{Et}_{3} \mathrm{~N} / \mathrm{DM} \mathrm{AP}$ at room temperature, yielding triacetoxy methyl cholanate 11, followed by the selective deacylation with $\mathrm{K}_{2} \mathrm{CO}_{3}$ in $\mathrm{MeOH}$ at room temperature

(13) Fieser, L. F.; Rajagopalan, S. J. Am. Chem. Soc. 1949, 41, 3935; $1950,72,5530 ; 1951,73,4133$.

(14) (a) Matkovics, B.; Samueisson, B. Acta. Chem. Scand. 1962, 16, 683. (b) Zaretskii, Z. V. Mass Spectrom. Steroids 1976, 119.

(15) (a) Oppenauer, R. V. Monatsch. 1966, 97, 62. (b) Welzel, P.; Hobert, K.; Milkova, T. Tetrahedron Lett. 1983, 24, 3199. 
<smiles>CC=C(C)C(=O)OC</smiles>

Figure 2.

Table 1. Comparison of Chemical Shifts for Acrylates

\begin{tabular}{ccccc}
\hline & \multicolumn{3}{c}{$\Delta \delta$} & \\
\cline { 2 - 3 } & $\mathbf{7}$ & $\mathbf{1 0}$ & $\mathbf{1 3}$ & $\delta$ of 14 \\
\hline $\mathrm{H}_{\mathrm{a}}$ & -0.194 & -0.096 & +0.004 & 5.800 \\
$\mathrm{H}_{\mathrm{b}}$ & -0.173 & -0.081 & +0.029 & 6.090 \\
$\mathrm{H}_{\mathrm{c}}$ & -0.223 & -0.11 & +0.011 & 6.388
\end{tabular}

to give alcohol 12 in $99 \%$ yield. ${ }^{16}$ Finally, compound 12 was converted to acrylate 13 in $63 \%$ yield. Compound 14, as an NMR reference, was prepared by the direct esterification of methyl cholate (2).

It is interesting to note that the introduction of the naphthalene unit at the C-7 position has remarkable anisotropic effects on the chemical shifts of the C-3 and C-12 substituents. A comparison of the ${ }^{1} \mathrm{H}-\mathrm{NMR}$ spectrum of compound 5 with that of its precursor $(4,7 \alpha-$ $\mathrm{OH}$, lacking the naphthalene unit) showed that the C-3 acetate signal in 5 was shielded by $0.18 \mathrm{ppm}$ whereas the C-12 acetate signal was deshielded by $0.08 \mathrm{ppm} .{ }^{17} \mathrm{~A}$ similar trend was also observed in the acrylate ester; all the three olefinic signals of acrylate ester 7 showed ca. $0.2 \mathrm{ppm}$ upfield shift compared to compound 14. For comparison, relevant NMR data of acrylate esters 7,10 , 13, and 14 (Figure 2) are listed in Table 1. These data suggested that the olefinic portion of acrylate ester 7 was well shielded by the $\pi$-cloud of the aromatic ring and, presumably, the double bond and the aromatic rings were approximately parallel.

Authentic samples of the Diels-Alder products of cyclopentadiene and acrylates 7,10 , and 13 were prepared in order to establish the stereochemical outcome of the reactions. Both partially enriched and racemic samples of endo-bicyclo[2.2.1]hept-5-ene-2-carboxylic acid were converted to the corresponding acid chlorides and esterified with steroidal alcohols 6, 9, and 12 in the presence of pyridine in $\mathrm{CH}_{2} \mathrm{Cl}_{2}$ at room temperature. ${ }^{18}$ The ${ }^{1} \mathrm{H}-\mathrm{NMR}$ spectrum of an authentic mixture of $15 \mathrm{a}$ $15 \mathrm{~b}$ (15b in $48 \%$ excess) showed two sets of olefinic signals for the two diastereomers. The minor diastereomer (15a, " $2 S$ ") showed two doublet of doublets at $\delta 5.78$ and 5.70 , whereas the major $(15 b, " 2 R$ ") isomer showed two doublet of doublets at $\delta 5.76$ and 4.95. Similarly, the acetoxy and the methoxy signals were also resolved. The $12 \alpha$-acetoxy and the side-chain methoxy signals were at $\delta 2.23$ and 3.598 , respectively, for diastereomer $15 \mathrm{a}$ and at $\delta 2.25$ and 3.603 for diastereomer 15b. For diastereomeric pairs $16 \mathrm{a} / \mathbf{1 6 b}$ and $17 \mathrm{a} / \mathbf{1 7 b}$, only one set of acetate signals resolved in high-field NMR. Other signals, notably the norbornene olefinic protons, did not resolve. Diastereomeric pairs $15 \mathrm{a} / 15 \mathrm{~b}$ and $16 \mathrm{a} / 16 \mathrm{~b}$ were also found to be separable by analytical HPLC on a C-18 column. ${ }^{19}$

(16) Plattner, Pl. A.; Heusser, H. Helv. Chim. Acta 1944, 27, 748. (17) The ${ }^{1} \mathrm{H}-\mathrm{NMR}$ shifts of the acetate signals were idendified by comparison of the spectra of 4 and 5 .

(18) We observed that the $2 R$ enantiomer reacted slightly faster than the $2 S$ enantiomer during the esterification of the racemic and partially enriched samples of norbornene carboxylic acid chlorides with steroidal alcohols 6 and 9 . The small degree of kinetic resolution caused by this did not affect our interpretations in any way.

(19) Preparative separation of these diastereomeric pairs was unsuccessful.
Table 2. Lewis Acid Catalyzed and Uncatalyzed

Diels-Alder Reaction of Steroidal Acrylates 7, 10, and 13 with Excess Cyclopentadiene in $\mathrm{CH}_{2} \mathrm{Cl}_{2}$

\begin{tabular}{|c|c|c|c|c|c|c|c|}
\hline entry & $\begin{array}{l}\text { com- } \\
\text { pound }\end{array}$ & $\begin{array}{c}\text { Lewis acid } \\
\text { (equiv) }\end{array}$ & $\stackrel{\text { temp }}{\left({ }^{\circ} \mathrm{C}\right)}$ & $\begin{array}{c}\text { time } \\
\text { (h) }\end{array}$ & $\underset{(\%)}{\text { yield }}$ & $\begin{array}{c}\text { endo: } \\
\text { exo }\end{array}$ & $\begin{array}{c}\text { endo de } \\
\text { (config) }\end{array}$ \\
\hline 1 & 13 & none & 0 & 48 & 80 & $c$ & $3(S)$ \\
\hline 2 & 13 & $\mathrm{BF}_{3} \cdot \mathrm{OEt}_{2}(8.3)$ & -40 & 12 & 60 & 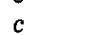 & $2(S)$ \\
\hline 3 & 7 & none & 0 & 36 & 92 & $79: 21$ & $36(R)$ \\
\hline 4 & 10 & none & 0 & 48 & 70 & $82: 18$ & $31(R)$ \\
\hline 5 & 7 & $\mathrm{TiCl}_{4}(3.0)$ & 0 & 25 & 82 & $>95$ & $27(S)$ \\
\hline 6 & 7 & $\mathrm{FeCl}_{3}(3.0)$ & -10 & 8 & 69 & $96: 4$ & $35(S)$ \\
\hline 7 & 7 & $\mathrm{SnCl}_{4}($ & -40 & 12 & 66 & $97: 3$ & $44(S)$ \\
\hline 8 & 7 & $\mathrm{ZnCl}_{2}$ & -40 & $14^{1 / 2}$ & 30 & $>95$ & $34(S)$ \\
\hline 9 & 7 & $\mathrm{AlCl}_{3}$ & -80 & 9 & 90 & $99: 1$ & $74(S)$ \\
\hline 10 & 7 & $\mathrm{AlC}$ & -40 & 8 & 65 & $98: 2$ & $63(S)$ \\
\hline 11 & 10 & $\mathrm{AlCl}$ & -20 & 5 & 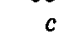 & $97: 3$ & $42(S)$ \\
\hline 12 & 7 & $\mathrm{BF}_{3} \cdot \mathrm{OEt}_{2}(2.1)$ & -80 & 12 & 87 & 99 & $79(S)$ \\
\hline 13 & 7 & $\mathrm{BF}_{3} \cdot \mathrm{OEt}_{2}(4$ & -80 & 12 & 98 & $>99$ & $85(S)$ \\
\hline 14 & 7 & $\mathrm{BF}_{3}$ & -80 & 10 & 86 & $>99.8$ & \\
\hline 15 & 7 & $\mathrm{BF}_{3} \cdot \mathrm{C}$ & -40 & 7 & 86 & 98.2 & $73(S)$ \\
\hline 16 & 7 & $\mathrm{BF}_{3} \cdot \mathrm{OEt}_{2}(10.4)$ & 0 & $2^{1 / 2}$ & $c$ & $97: 3$ & $53(S)$ \\
\hline 17 & 7 & $\mathrm{BF}_{3} \cdot \mathrm{OEt}_{2}(11.2)$ & 0 & $2^{1 / 2}$ & $c$ & $96: 4$ & $26(S)^{d}$ \\
\hline 18 & 10 & $\mathrm{BF}_{8^{\circ}}$ & -40 & 8 & 93 & $98:$ & $64(S)$ \\
\hline 19 & 10 & $\mathrm{BF}_{3} \cdot \mathrm{OEt}_{2}(10.0)$ & 0 & $2^{1 / 2}$ & 92 & $96: 4$ & $37(S)$ \\
\hline
\end{tabular}

a endo/exo ratios were calculated by HPLC data. ${ }^{b}$ de were calculated from ${ }^{1} \mathrm{H}-\mathrm{NMR}$ and HPLC data. The configuration refers to the stereochemistry of C-2 of the bicyclo[2.2.1] system. ${ }^{c}$ Not determined. ${ }^{d}$ Reaction was carried out in toluene.

Diels-Alder reactions of 7,10 , and 13 with cyclopentadiene were carried out in $\mathrm{CH}_{2} \mathrm{Cl}_{2}$ under various conditions, and the results are summarized in Table 2 . It is noteworthy that compound 13, lacking a shielding unit at C-7, did not show any significant stereoselectivity either in uncatalyzed or catalyzed reactions (entries 1 and 2 ). On the other hand, the reaction of acrylates $\mathbf{7}$ and 10 in the absence of any catalyst at $0{ }^{\circ} \mathrm{C}$ (entries 3 and 4) gave the endo and exo products (ratio ca. 4:1) with $36 \%$ de (15b major) and $31 \%$ de (16b major), respectively (Scheme 2). Lewis acid catalyzed reactions showed very high endo selectivity (>95\%) in most cases and, more interestingly, reversed the stereochemical outcome. We found that with acrylate 7 , the use of $\mathrm{TiCl}_{4}, \mathrm{FeCl}_{3}, \mathrm{SnCl}_{4}$, and $\mathrm{ZnCl}_{2}$ as Lewis acids gave low to moderate levels of diastereoselectivity $(27-44 \%$, in favor of 15a) in the endo cycloadduct (entries 5 to 8 ).

Aluminum chloride and boron trifluoride etherate were found to be more effective catalysts. $\mathrm{AlCl}_{3}$-catalyzed cycloaddition with $7\left(-80\right.$ and $\left.-40^{\circ} \mathrm{C}\right)$ and $10\left(-20^{\circ} \mathrm{C}\right)$ afforded corresponding products with $74 \%, 63 \%$, and $42 \%$ de, respectively (entries 9 to 11). Under similar conditions $\left(-80^{\circ} \mathrm{C}\right.$ for 7 and $-40{ }^{\circ} \mathrm{C}$ for 10$)$, the use of an excess of $\mathrm{BF}_{3} \cdot \mathrm{OEt}_{2}{ }^{20}$ yielded the cycloadducts with $88 \%$ and $64 \%$ de, respectively (entries 14 and 18 ). We have carried out a systematic study of the quantity of $\mathrm{BF}_{3} \cdot \mathrm{OEt}_{2}$ (2.1 to 10.6 equiv, entries 12 to 14 ), temperature ( 0 to $-80{ }^{\circ} \mathrm{C}$, entries 14,15 , and 16 ), and solvent (toluene) (entries 16 and 17), ${ }^{21}$ and the results indicate (details in supplementary material) that the conditions shown in entries 14 and 18 are optimum for the two substrates.

The observation that the highest diastereoselection was achieved by the use of more than 4 equiv of $\mathrm{BF}_{3} \cdot \mathrm{OEt}_{2}$

(20) For the $\mathrm{BF}_{3} \cdot \mathrm{OEt}_{2}$-catalyzed reactions, the number of equivalents reported in ref $10 \mathrm{~b}$ are to be multiplied by the factor of 2.1 .

(21) Cycloaddition of the acrylate 7 was also performed in water in the presence of $\beta$-cyclodextrin at $5^{\circ} \mathrm{C}$. The acrylate was precomplexed with $\beta$-cyclodextrin. At $30 \%$ conversion $(5 \mathrm{~h}$ ), cycloadducts $15 \mathrm{a} / \mathbf{1 5 b}$ were produced with $26 \%$ de $(2 R)$ in the endo adduct (endo/exo $=79 /$ 21). The same reaction carried out in excess cyclopentadiene at room temperature gave the adducts with low diastereoselectivity $(12 \%, 2 R)$. There was no reaction in ether and THF at low temperature, presumably because of the deactivation of the Lewis acids (We thank the American Maize Co. for a gift sample of $\beta$-cyclodextrin). 


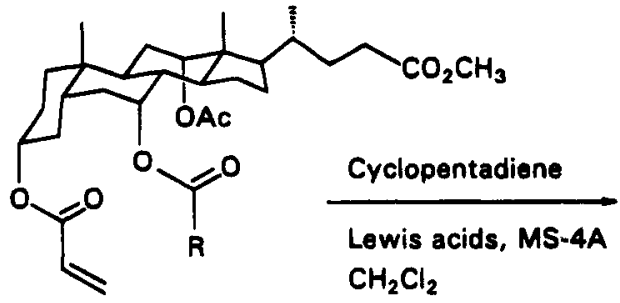

$7(R=2-$ Naphthyl)

$10(R=4-B i p h e n y)$

$13(R=$ Methyl)
Scheme 2

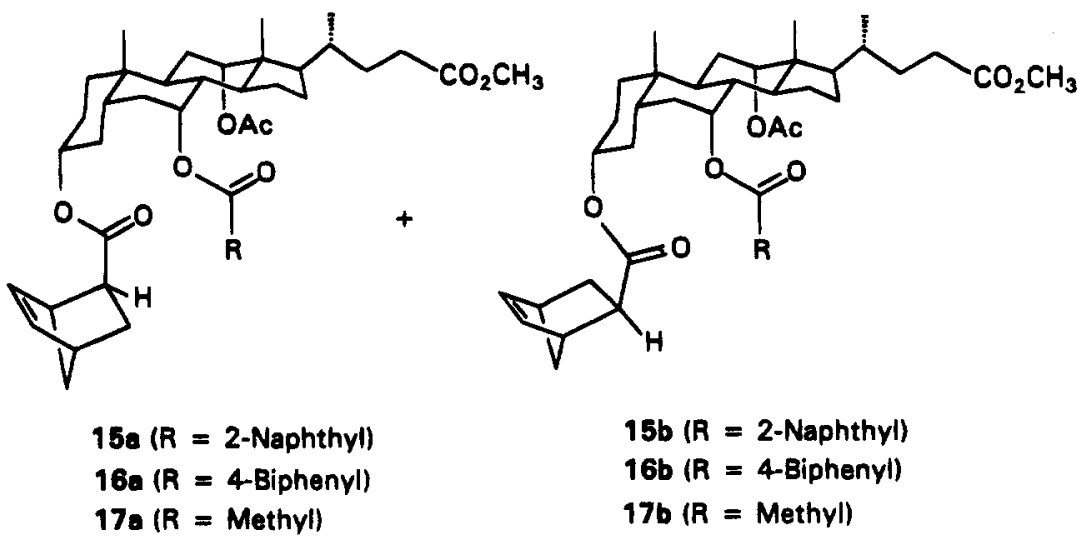

suggests that with lesser amounts of $\mathrm{BF}_{3} \cdot \mathrm{OEt}_{2}$ the acrylate ester does not get fully complexed because of competition from other the ester groups. ${ }^{22}$ The effectiveness of the Lewis acids in diastereoselection were found to follow the following order: $\mathrm{BF}_{3} \cdot \mathrm{OEt}_{2}>\mathrm{AlCl}_{3}>\mathrm{SnCl}_{4}$ $>\mathrm{ZnCl}_{2} \approx \mathrm{TiCl}_{4} \approx \mathrm{FeCl}_{3}$.

Uncatalyzed and the Lewis acids catalyzed reactions yielded products with opposite configurations. The stereochemical outcome of these reactions may be rationalized in terms of dienophile orientations. We believe that under uncatalyzed conditions, the reaction proceeds via an s-trans orientation whereas under the Lewis acid promoted conditions the reaction proceeds via an $s$-cis conformation. ${ }^{23}$

Under identical conditions acrylate ester 10 showed less diastereoselection when compared to the corresponding naphthoate ester 7 (entries 3 and 4, 15 and 18, 16 and 19). On the other hand, acrylate ester 13 showed virtually no selectivity in either catalyzed or uncatalyzed reactions (entries 1 and 2 ). The above results confirm that our concept of introducing a large and flat aromatic nucleus at C-7 position to shield one face of the double bond was correct. The presence of the naphthalene unit at $\mathrm{C}-7$ position effectively shields the olefinic part, rendering the entry of cyclopentadiene from the other side of the olefin as shown in Figure 3.

Attempts to remove the cycloadduct from the steroidal framework under a variety of basic conditions were unsuccessful. ${ }^{24}$ It has been shown that $\beta, \gamma$-unsaturated esters upon treatment with $I_{2}$ undergoes cyclization to

(22) Soai, K.; Ishizaki, M. J. Org. Chem. 1987, 513290.

(23) It is known that an $\alpha, \beta$-unsaturated ester under chelation control adopts an $s$-cis conformation; the same conformation is also enforced when the carbonyl group bears large substituents. (a) Loncharich, B. J.; Schwartz, T. R.; Houk, K. N. J. Am. Chem. Soc. 1987, 109, 14. (b) Choy, W.; Reed, L. A., III; Masamune, S. J. Org. Chem. $1883,48,1137$.

(24) Under conventional methods of base hydrolysis (alcoholysis), the adducts failed to give the corresponding acid (ester) and the alcohol see ref 3(b): (a) $\mathrm{LiOH}, \mathrm{THF} / \mathrm{H}_{2} \mathrm{O}$; (b) $\mathrm{LiOH} / \mathrm{H}_{2} \mathrm{O}_{2}, \mathrm{THF} / \mathrm{H}_{2} \mathrm{O}$; (c) anhydrous $\mathrm{K}_{2} \mathrm{CO}_{3}, \mathrm{MeOH}$, $\mathrm{rt}$ and reflux conditions; and (d) $\mathrm{BnOLi}$ $\mathrm{THF},-78$ to $0^{\circ} \mathrm{C}$

(25) (a) Bartlett, P. A.; Myerson, J. J. Am. Chem. Soc. 1978, 100, 3950. (b) It has been shown by Giese that in bicyclo[2.2.1]hept-5-ene series, compounds containing a carboxylic acid as well as a methoxycarbonyl group reacted with $I_{2}$ at room temperature to a mixture of iodo lactones, involving the participation of both carboxyl groups. The effectiveness of these groups are in the following order: $\mathrm{COO}^{-}>\mathrm{COOH}$ $>\mathrm{COOMe}=\mathrm{COOEt}$. Giese, B. Chem. Ber, 1977, 108, 2978. (c) A similar strategy was employed for amide-based chiral auxiliaries. Kawanami, Y.; Katsuki, T.; Yamaguchi, M. Bull. Chem. Soc. Jpn. 1987, 60,4190 . (d) Treatment of $\beta, \gamma$-unsaturated esters with either (symcollidine $)_{2} \mathrm{I}^{+} \mathrm{ClO}_{4}{ }^{-}$in $\mathrm{CH}_{2} \mathrm{Cl}_{2}$ or $\mathrm{N}$-iodosuccinimide in $\mathrm{CF}_{3} \mathrm{SO}_{3} \mathrm{H}$ in presence of MS 4A afforded corresponding iodo lactones and alcohols. Kunz, H.; Wernig, P.; Schultz, M. Synlett. 1990, 631.

(26) Kirmse, W.; Siegfried, R. J. Am. Chem. Soc. 1983, 105, 950. the corresponding iodo lactones. ${ }^{25 d}$ We found that the cycloadduct can be released from the steroidal unit by a conventional iodolactonization method. ${ }^{25}$ Treatment of cycloadducts $\mathbf{1 5 a} / \mathbf{1 5 b}$ in a biphasic mixture of $\mathrm{I}_{2}, \mathrm{KI}$, and $\mathrm{NaHCO}_{3}$ in $\mathrm{CH}_{2} \mathrm{Cl}_{2} / \mathrm{H}_{2} \mathrm{O}$ at room temperature regenerated chiral auxiliary $6(88 \%)$ and yielded enantiomeric iodo lactones $18 \mathrm{a} / 18 \mathrm{~b}(75 \%)$ (Scheme 3 ). The enantiomeric excess of the iodo lactone was found to be in good agreement with the observed de of cycloadduct $\mathbf{1 5 a} / \mathbf{1 5 b} .^{26}$

In conclusion, we have shown in this paper the development of a new class of chiral auxiliaries constructed easily from readily available cholic acid. The effectiveness of these auxiliaries has been demonstrated by carrying out highly diastereoselective Diels-Alder

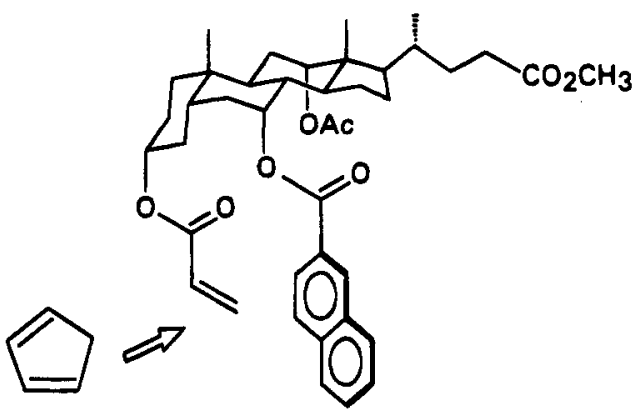

Figure 3.

Scheme 3

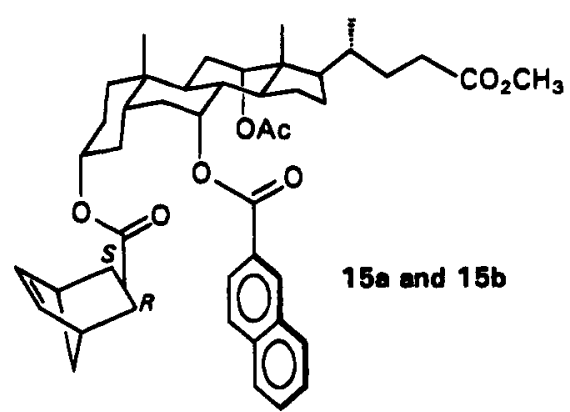

$$
\begin{aligned}
& \mathrm{I}_{2} / \mathrm{KI}, \mathrm{CH}_{2} \mathrm{Cl}_{2} \\
& \text { aq. } \mathrm{NaHCO}_{3}, \mathrm{rt}, 2 \mathrm{~h}
\end{aligned}
$$<smiles>O=C1OC2CC1CC2I</smiles>

$18 \mathrm{a}$

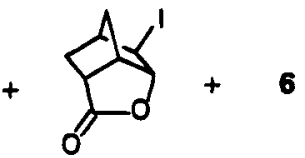

$18 b$ 
reactions. Acrylate 7 derived from alcohol 6 has been found superior to alcohols $\mathbf{1 0}$ and $\mathbf{1 2}$ in the Lewis acid catalyzed Diels-Alder reactions with cyclopentadiene. The presence of a flat naphthalene surface was essential to induce a high level of asymmetric induction in the cycloaddition reaction. Replacement of the flat naphthalene unit at C-7 by a biphenyl moiety decreased the diastereoselectivity whereas an acetate group at C-7 did not show any selectivity. Iodolactonization-induced cleavage was employed to regenerate the chiral auxiliaries and to isolate the cycloadduct. One-step conversion of the bicyclic carboxylic esters into their iodo lactones was also achieved. Application of bile acid based chiral auxiliaries to other areas of asymmetric synthesis is in progress. ${ }^{27}$

\section{Experimental Section}

General Comments. All reactions were conducted under dry nitrogen and stirred magnetically unless otherwise stated. When anhydrous conditions were required, the glassware was flame dried under high vacuum and then filled with dry nitrogen while cooling. Reaction temperatures refer to external or bath temperatures, unless indicated otherwise. Analytical TLC was performed on plates made from Acme silica gel or on precoated $(0.25 \mathrm{~mm})$ silica gel $60 \mathrm{~F}-254$ plates purchased from $\mathrm{E}$. Merck. Visualization was done under UV $(254 \mathrm{~nm})$ radiation or by dipping the plates in $5 \%$ ethanolic phosphomolybdic acid solution and heating. Columns for chromatography were made from 60-120 mesh silica gel. All solvents were purified and distilled before use. Toluene, benzene, tetrahydrofuran, and ether were distilled from sodium/benzophenone ketyl. Methanol, methylene chloride, and acetic anhydride were distilled from magnesium methoxide, $\mathrm{CaH}_{2}$, and phosphorous pentoxide, respectively. Pyridine and triethylamine were stored over $\mathrm{KOH}$ and distilled from $\mathrm{CaH}_{2}$. Melting points were recorded in open capillaries and are uncorrected. Optical rotations were measured at $589 \mathrm{~nm}$ in a $0.2 \mathrm{~mL}$ cell at specified temperatures. IR spectra were recorded using $\mathrm{NaCl}$ cells and reported in $\mathrm{cm}^{-1}$. NMR spectra were recorded in 200,270 , and $400 \mathrm{MHz}$ instruments in $\mathrm{CDCl}_{3}$ solution using TMS as the internal standard. Chemical shifts are reported in $\delta$ and coupling constants in hertz; s, d, q, and $m$ refer to singlet, doublet, quartet, and multiplets, respectively. HPLC analysis was carried out using a $250 \times 4.6 \mathrm{~mm}$ i.d. ODS column (Shimadzu) with a mobile phase of methanol and water $(90: 10 \mathrm{v} / \mathrm{v}$ for $\mathbf{1 5 a} / \mathbf{1 5 b}$ and $95: 5 \mathrm{v} / \mathrm{v}$ for $\mathbf{1 6 a} / \mathbf{1 6 b})$. The mean retention times of compounds $15 \mathbf{a}, 15 \mathbf{b}, \mathbf{1 6 a}$, and $16 \mathrm{~b}$ were $23.28,21.17,12.39$, and $11.56 \mathrm{~min}$, respectively.

Methyl 3 $\alpha, 12 \alpha$-Diacetoxy-7-keto-5 $\beta$-cholanate (3). To a stirred solution of methyl 7-ketocholate $(2.45 \mathrm{~g}, 5.84 \mathrm{mmol})$ and DMAP (0.144 g, $1.18 \mathrm{mmol})$ in $\mathrm{Et}_{3} \mathrm{~N}(12.0 \mathrm{~mL}, 8.76 \mathrm{~g}, 86.6$ $\mathrm{mmol}$ ) was added acetic anhydride $(5.8 \mathrm{~mL}, 6.26 \mathrm{~g}, 61.4 \mathrm{mmol})$. After the mixture was stirred for $24 \mathrm{~h}$ at room temperature, water was added, and the product was extracted with ethyl acetate, washed with water, dilute $\mathrm{HCl}$, water, and brine, dried (anhydrous $\mathrm{Na}_{2} \mathrm{SO}_{4}$ ), and evaporated to dryness in vacuo. The crude product was purified by column chromatography (20\% ethyl acetate/hexanes) to yield $3(2.64 \mathrm{~g}, 90 \%)$ as a colorless foam. Crystallization from ethyl acetate/hexanes gave a colorless solid: $\mathrm{mp} 122{ }^{\circ} \mathrm{C}$ (lit. $\left.{ }^{15} \mathrm{mp} 115.5^{\circ} \mathrm{C}\right) ;{ }^{1} \mathrm{H} \mathrm{NMR}\left(\mathrm{CDCl}_{3}\right.$, $200 \mathrm{MHz}) \delta 5.09(\mathrm{br} \mathrm{s}, 1 \mathrm{H}), 4.66(\mathrm{br} \mathrm{s}, 1 \mathrm{H}), 3.66(\mathrm{~s}, 3 \mathrm{H}), 2.89$ $(\mathrm{d}, 1 \mathrm{H}, J=6.3 \mathrm{~Hz}), 2.83(\mathrm{~d}, 1 \mathrm{H}, J=6.2 \mathrm{~Hz}), 2.45-0.73(\mathrm{br} \mathrm{m}$, steroidal $\mathrm{CH}_{2}$ and $\left.\mathrm{CH}\right), 2.00(\mathrm{~s}, 3 \mathrm{H}), 1.19(\mathrm{~s}, 3 \mathrm{H}), 0.81(\mathrm{~d}, 3 \mathrm{H}$, $J=6.0 \mathrm{~Hz}), 0.73(\mathrm{~s}, 3 \mathrm{H})$

Methyl 3 $\alpha, 12 \alpha$-Diacetoxy-7 $\alpha$-hydroxy-5 $\beta$-cholanate (4). To a stirred solution of compound $3(2.38 \mathrm{~g}, 4.72 \mathrm{mmol})$ in $\mathrm{MeOH}(30 \mathrm{~mL})$ was added $\mathrm{NaBH}_{4}(0.18 \mathrm{~g}, 4.76 \mathrm{mmol})$ at $0{ }^{\circ} \mathrm{C}$. After the solution was stirred for $1 \mathrm{~h}$ at $0^{\circ} \mathrm{C}$, the reaction was quenched by adding acetone. The solvent was evaporated, and the resulting solid was stirred with ethyl acetate. The organic extract was washed with water and brine, dried, and finally

(27) We thank two anonymous referees for their useful comments and suggestions. evaporated to dryness. The crude product was purified by column chromatography on silica gel (20\% ethyl acetate/ hexanes) to yield $4(1.983 \mathrm{~g}, 83 \%)$ as a colorless solid. Crystallization from ethyl acetate/hexanes gave a colorless solid: $\mathrm{mp} 140{ }^{\circ} \mathrm{C}$ (lit. $\left..^{15} \mathrm{mp} 143-145^{\circ} \mathrm{C}\right) ;{ }^{1} \mathrm{H} \mathrm{NMR}\left(\mathrm{CDCl}_{3}, 200\right.$ $\mathrm{MHz}) \delta 5.10(\mathrm{br} \mathrm{s}, 1 \mathrm{H}), 4.57(\mathrm{br} \mathrm{m}, 1 \mathrm{H}), 3.90(\mathrm{br} \mathrm{s}, 1 \mathrm{H}), 3.66$ (s, 3H), 2.41-0.69 (br m, steroidal $\mathrm{CH}_{2}$ and $\mathrm{CH}$ ), 2.11 (s, 3H), $2.02(\mathrm{~s}, 3 \mathrm{H}), 0.89(\mathrm{~s}, 3 \mathrm{H}), 0.81(\mathrm{~d}, 3 \mathrm{H}, J=6.5 \mathrm{~Hz}), 0.74(\mathrm{~s}$, $3 \mathrm{H}) ;{ }^{13} \mathrm{C} \mathrm{NMR}\left(\mathrm{CDCl}_{3}, 22.5 \mathrm{MHz}\right) \delta 174.3,170.4,75.4,74.2$, $67.8,51.3,47.3,44.9,43.4,41.1,39.2,35.1,34.4,30.7,27.6$, 27.3, 26.7, 25.4, 22.7, 22.5, 21.3, 17.4, 12.1; IR (Nujol) 3544, $1749,1731,1716 \mathrm{~cm}^{-1} ;[\alpha]^{21} \mathrm{D}=+82.7^{\circ}\left(\mathrm{c} 1.6, \mathrm{CHCl}_{3}\right)$. Anal. Calcd for $\mathrm{C}_{29} \mathrm{H}_{46} \mathrm{O}_{7}$ : C, 68.77; $\mathrm{H}, 9.09$. Found: $\mathrm{C}, 68.61 ; \mathrm{H}$, 9.34 .

Methyl 3 $\alpha, 12 \alpha-D i a c e t o x y-7 \alpha-(2-n a p h t h o y l o x y)-5 \beta$-cholanate (5). To a stirred mixture of compound $4(2.592 \mathrm{~g}, 5.12$ $\mathrm{mmol}), \mathrm{CaH}_{2}(1.139 \mathrm{~g}, 27.05 \mathrm{mmol})$, and $n-\mathrm{Bu} 4 \mathrm{NI}(0.978 \mathrm{~g}, 2.69$ $\mathrm{mmol})$ in toluene $(25 \mathrm{~mL})$ was added naphthalene-2-carboxylic acid chloride (1.525 $\mathrm{g}, 7.998 \mathrm{mmol})$. The mixture was refluxed for $24 \mathrm{~h}$, cooled, and filtered through a pad of Celite. The residue was washed with ethyl acetate, and the combined filtrate and the washings were evaporated to dryness in vacuo. Purification by column chromatography on silica gel (20\% ethyl acetate/hexanes) yielded product $5(2.928 \mathrm{~g}, 86.6 \%)$ as a colorless foam. Crystallization from ethyl acetate/hexanes gave a colorless solid: $\mathrm{mp} 199-200^{\circ} \mathrm{C} ;{ }^{1} \mathrm{H}$ NMR $\left(\mathrm{CDCl}_{3}, 200\right.$ $\mathrm{MHz}) \delta 8.62(\mathrm{~s}, 1 \mathrm{H}), 8.09(\mathrm{dd}, 1 \mathrm{H}, J=8.5$ and $1.7 \mathrm{~Hz}), 7.97-$ $7.89(\mathrm{~m}, 3 \mathrm{H}), 7.65-7.58(\mathrm{~m}, 2 \mathrm{H}), 5.28$ (apparent d, $1 \mathrm{H}, J=$ $2.7 \mathrm{~Hz}), 5.16\left(\mathrm{~s}, \mathrm{w}_{1 / 2}=7.6 \mathrm{~Hz}, 1 \mathrm{H}\right), 4.57\left(\mathrm{br} \mathrm{m}, \mathrm{w}_{1 / 2}=25.3 \mathrm{~Hz}\right.$, $1 \mathrm{H}), 3.61(\mathrm{~s}, 3 \mathrm{H}), 2.38-0.77$ (br m, steroidal $\mathrm{CH}_{2}$ and $\mathrm{CH}$ ), 2.19 $(\mathrm{s}, 3 \mathrm{H}), 1.84(\mathrm{~s}, 3 \mathrm{H}), 0.99(\mathrm{~s}, 3 \mathrm{H}), 0.82(\mathrm{~d}, 3 \mathrm{H}, J=6.2 \mathrm{~Hz})$, $0.77(\mathrm{~s}, 3 \mathrm{H}) ;{ }^{13} \mathrm{C} \mathrm{NMR}\left(\mathrm{CDCl}_{3}, 22.5 \mathrm{MHz}\right) \delta 174.4,170.5,170.2$, 165.5, 135.6, 132.7, 131.2, 129.2, 128.1, 127.9, 126.8, 125.3, $75.5,73.8,71.6,51.4,47.4,45.1,43.4,40.8,38.4,35.1,34.6$, $31.6,30.8,28.9,27.1,26.9,25.4,23.0,22.6,21.3,17.6,12.3$; IR (film) 2920, 2854, 1746, $1713 \mathrm{~cm}^{-1}$; MS $(\mathrm{m} / z) 660,485,428$, $368,253,155(100), 105,43 ;[\alpha]^{25} \mathrm{D}=+100.8^{\circ}\left(c 1.45, \mathrm{CHCl}_{3}\right)$. Anal. Calcd for $\mathrm{C}_{40} \mathrm{H}_{52} \mathrm{O}_{8}$ : $\mathrm{C}, 72.71 ; \mathrm{H}, 7.88$. Found: $\mathrm{C}, 72.69$; H, 7.99.

Methyl 12 $\alpha$-Acetoxy-3 $\alpha$-hydroxy-7 $\alpha$-(2-naphthoyloxy)$5 \beta$-cholanate (6). Anhydrous $\mathrm{K}_{2} \mathrm{CO}_{3}(1.157 \mathrm{~g}, 8.37 \mathrm{mmol}$ ) was added to a solution of compound $\mathbf{5}(3.094 \mathrm{~g}, 4.687 \mathrm{mmol})$ in $\mathrm{MeOH}(55 \mathrm{~mL})$ at room temperature. After the reaction mixture was stirred for $71 / 2 \mathrm{~h}$, the reaction was quenched with acetic acid $(1 \mathrm{~mL})$. The solvent was evaporated, and the resulting crude product was extracted with ethyl acetate. The combined organic layers were washed with water and brine and dried over anhydrous $\mathrm{Na}_{2} \mathrm{SO}_{4}$. After evaporation of the solvent, the residue was purified by column chromatography on silica gel ( $20 \%$ ethyl acetate/hexanes) to give 6 ( $2.602 \mathrm{~g}$, $90 \%$ ) as a foam. Crystallization from ethyl acetate/hexanes gave a colorless solid: $\mathrm{mp} 148-150{ }^{\circ} \mathrm{C} ;{ }^{1} \mathrm{H}$ NMR $\left(\mathrm{CDCl}_{3}, 200\right.$ $\mathrm{MHz}) \delta 8.63(\mathrm{~s}, 1 \mathrm{H}), 8.086(\mathrm{dd}, 1 \mathrm{H}, J=8.6$ and $1.6 \mathrm{~Hz}), 7.97-$ $7.88(\mathrm{~m}, 3 \mathrm{H}), 7.65-7.52(\mathrm{~m}, 2 \mathrm{H}), 5.26$ (apparent $\mathrm{d}, 1 \mathrm{H}, J=$ $2.6 \mathrm{~Hz}), 5.16(\mathrm{~s}, 1 \mathrm{H}), 3.60(\mathrm{~s}, 3 \mathrm{H}), 3.59(\mathrm{br} \mathrm{m}, 1 \mathrm{H}), 2.20(\mathrm{~s}, 3 \mathrm{H})$, $0.99(\mathrm{~s}, 3 \mathrm{H}), 0.82(\mathrm{~d}, 3 \mathrm{H}, J=6.2 \mathrm{~Hz}), 0.77(\mathrm{~s}, 3 \mathrm{H}) ;{ }^{13} \mathrm{C}$ NMR $\left(\mathrm{CDCl}_{3}, 67.5 \mathrm{MHz}\right) \delta 174.3,170.0,165.8,135.7,135.7,132.8$, $131.1,129.3,128.3,127.6,126.8,125.2,75.5,71.8,71.5,51.3$, $47.5,45.2,43.4,41.1,39.6,38.6,35.1,34.7,34.5,31.7,31.0$, $30.8,30.8,29.0,27.1,25.5,23.0,22.5,21.2,17.6,12.1$; IR (film) $3526,3442,2920,2854,1731,1713 \mathrm{~cm}^{-1}$; MS $(\mathrm{m} / \mathrm{z}) 618,386$ $(100), 368,253,155 ;[\alpha]^{25}{ }_{\mathrm{D}}=+62.9^{\circ}\left(c 0.85, \mathrm{CHCl}_{3}\right)$. Anal. Calcd for $\mathrm{C}_{38} \mathrm{H}_{50} \mathrm{O}_{7}: \mathrm{C}, 73.76 ; \mathrm{H}, 8.14$. Found. C, 74.14; $\mathrm{H}$, 8.31.

Methyl $12 \alpha$-Acetoxy-3 $\alpha$-(acryloyloxy)-7 $\alpha$-(naphthoyloxy)-5 $\beta$-cholanate (7). To a stirred solution of alcohol $6(0.62$ $\mathrm{g}, 1.0 \mathrm{mmol})$ and triethylamine $(0.44 \mathrm{~mL}, 0.32 \mathrm{~g}, 3.17 \mathrm{mmol})$ in $\mathrm{CH}_{2} \mathrm{Cl}_{2}(10 \mathrm{~mL})$ was added acryloyl chloride $(0.14 \mathrm{~mL}, 0.16$ $\mathrm{g}, 1.76 \mathrm{mmol}$ ) at $0^{\circ} \mathrm{C}$. After the reaction mixture was stirred at $0{ }^{\circ} \mathrm{C}$ for $2 \mathrm{~h}$, the reaction was quenched by addition of water. Usual aqueous workup, followed by purification on a silica gel column (20\% ethyl acetate/hexanes), afforded acrylate 7 (0.580 $\mathrm{g}, 87 \%$ ) as a colorless foam. Crystallization from ethyl acetate/ hexanes gave a colorless solid: $\mathrm{mp} 173^{\circ} \mathrm{C} ;{ }^{1} \mathrm{H}$ NMR $\left(\mathrm{CDCl}_{3}\right.$, $400 \mathrm{MHz}) \delta 8.619(\mathrm{~s}, 1 \mathrm{H}), 6.17(\mathrm{dd}, 1 \mathrm{H}, J=17.3$ and $1.5 \mathrm{~Hz})$, $5.92(\mathrm{dd}, 1 \mathrm{H}, J=17.3$ and $10.4 \mathrm{~Hz}$ ), $5.61(\mathrm{dd}, 1 \mathrm{H}, J=10.4$ 
and $1.5 \mathrm{~Hz}), 5.29(\mathrm{br} \mathrm{s}, 1 \mathrm{H}), 5.17(\mathrm{br} \mathrm{s}, 1 \mathrm{H}), 4.66(\mathrm{~m}, 1 \mathrm{H}), 3.60$ $(\mathrm{s}, 3 \mathrm{H}), 2.19(\mathrm{~s}, 3 \mathrm{H}), 1.01(\mathrm{~s}, 3 \mathrm{H}), 0.815(\mathrm{~d}, 3 \mathrm{H}, J=6.5 \mathrm{~Hz})$, $0.772(\mathrm{~s}, 3 \mathrm{H}) ;{ }^{13} \mathrm{C} \mathrm{NMR}\left(\mathrm{CDCl}_{3}, 100.6 \mathrm{MHz}\right) \delta 174.2,170.0$, $165.3,165.3,135.3,132.3,130.9,129.8,129.0,128.6,128.1$, $127.9,127.8,127.6,126.5,125.0,75.2,73.7,71.3,51.2,47.1$, $34.4,34.3,34.2,31.3,30.6,30.4,28.6,26.9,26.6,25.1,22.7$, $22.3,21.0,17.3,11.9 ; \mathrm{MS}(\mathrm{m} / \mathrm{z}) 672\left(\mathrm{M}^{+}\right), 440(58), 253(88)$, $172(100) ;[\alpha]^{25}=+99.4^{\circ}\left(c \quad 0.8, \mathrm{CHCl}_{3}\right)$. Anal. Calcd for $\mathrm{C}_{41} \mathrm{H}_{52} \mathrm{O}_{8}: \mathrm{C}, 73.27 ; \mathrm{H}, 7.74$. Found: $\mathrm{C}, 73.27 ; \mathrm{H}, 7.88$.

General Procedure for the Lewis Acid Catalyzed Diels-Alder Reactions. In a typical experiment, the chiral acrylate, powdered $4 \mathrm{~A}$ molecular sieve ("MS-4A"), and a small magnetic stir bar were taken in a three necked flask fitted with a rubber septum, a nitrogen balloon, and a bent tube with a stopcock. The flask was warmed, evacuated, and then flushed with nitrogen. After repeating this process the flask was allowed to cool under a positive pressure of nitrogen. Dry $\mathrm{CH}_{2} \mathrm{Cl}_{2}$ was added via a syringe, and the flask was cooled using a low-temperature bath. To the cooled stirred solution was added the appropriate Lewis acid at the specified temperature, and after 5 to $10 \mathrm{~min}$ freshly distilled cyclopentadiene was added slowly via syringe. The reaction was worked up by pouring water and $\mathrm{CH}_{2} \mathrm{Cl}_{2}$ into the reaction flask, and the product was extracted with methylene chloride. The organic solution was washed thoroughly with water, $7 \% \mathrm{NaHCO}_{3}$ solution, water, and brine and finally dried over anhydrous $\mathrm{Na}_{2} \mathrm{SO}_{4}$. Filtration and removal of the solvent yielded the crude product, which was purified by column chromatography to give the pure product.

$\mathrm{BF}_{3} \cdot \mathrm{OEt}_{2}$-Catalyzed Diels-Alder Reaction between Chiral Acrylate 7 and Cyclopentadiene. A mixture of chiral acrylate $7(0.32 \mathrm{~g}, 0.476 \mathrm{mmol}), \mathrm{MS} 4 \mathrm{~A}(100 \mathrm{mg})$, and $\mathrm{CH}_{2} \mathrm{Cl}_{2}(15 \mathrm{~mL})$ was cooled to $-80^{\circ} \mathrm{C}$ and $\mathrm{BF}_{3} \cdot \mathrm{OEt}_{2}(0.62 \mathrm{~mL}$, $0.72 \mathrm{~g}, 5.04 \mathrm{mmol}$ ) was added followed by the slow addition of cyclopentadiene $(1.0 \mathrm{~mL}, 0.8 \mathrm{~g}, 12.1 \mathrm{mmol}$ ) over a period of 15 min. After completion of the reaction $(10 \mathrm{~h})$, it was worked up as mentioned above and the resulting crude product was purified by column chromatography on silica gel (60-120 mesh, $28 \times 2 \mathrm{~cm}$ ) using (20\% ethyl acetate/hexanes). A diastereomeric mixture of cycloadducts $15 \mathrm{a} / 15 \mathrm{~b}(0.300 \mathrm{~g}, 86 \%)$ was isolated as a colorless solid: IR (film) 2938, 1734, 1635 $\mathrm{cm}^{-1}$; ${ }^{1} \mathrm{H} \mathrm{NMR}\left(\mathrm{CDCl}_{3}, 400 \mathrm{MHz}\right.$ ) data for compound $15 \mathrm{a}$ (major diastereomer), $\delta 8.62(\mathrm{br} \mathrm{s}, 1 \mathrm{H}), 8.12-8.1(\mathrm{q}, 1 \mathrm{H}), 7.95-$ $7.91(\mathrm{~m}, 3 \mathrm{H}), 7.62-7.54(\mathrm{~m}, 2 \mathrm{H}), 5.78(\mathrm{dd}, 1 \mathrm{H}, J=3.0$ and 6.0 $\mathrm{Hz}$ ), $5.71(\mathrm{dd}, 1 \mathrm{H}, J=3.0$ and $6.0 \mathrm{~Hz}), 5.26(\mathrm{br} \mathrm{s}, 1 \mathrm{H}), 5.18(\mathrm{~s}$, $1 \mathrm{H}), 4.5(\mathrm{br} \mathrm{m}, 1 \mathrm{H}), 3.60(\mathrm{~s}, 3 \mathrm{H}), 3.0(\mathrm{br} \mathrm{s}, 1 \mathrm{H}), 2.63-2.66(\mathrm{~m}$ $1 \mathrm{H}), 2.3-0.77\left(\mathrm{br} \mathrm{m}\right.$, steroidal $\mathrm{CH}_{2}$ and $\left.\mathrm{CH}\right), 2.22(\mathrm{~s}, 3 \mathrm{H}), 0.99$ $(\mathrm{s}, 3 \mathrm{H}), 0.83(\mathrm{~d}, 3 \mathrm{H}, J=6.5 \mathrm{~Hz}), 0.77(\mathrm{~s}, 3 \mathrm{H}) ;{ }^{13} \mathrm{C} \mathrm{NMR}\left(\mathrm{CDCl}_{3}\right.$, $100 \mathrm{MHz}) \delta 174.5,174.0,170.3,165.4,137.5,135.6,132.6$, $132.4,131.1,129.3,128.4,128.3,128.1,127.9,126.8,125.4$ $75.6,73.3,71.7,51.5,49.3,47.4,45.1,43.6,43.3,42.3,40.7$, $38.4,35.1,34.6,34.4,31.4,30.9,30.7,29.3,28.8,27.2,26.8$, $25.3,23.0,22,5,21.3,17.6,12.2 ; \mathrm{MS}(\mathrm{m} / z) 738\left(\mathrm{M}^{+}\right), 672(\mathrm{M}-$ $\mathrm{C}_{5} \mathrm{H}_{6}$ ), 440, 253, 155 (100). Anal. Calcd for $\mathrm{C}_{46} \mathrm{H}_{58} \mathrm{O}_{8}: \mathrm{C}, 74.77$ $\mathrm{H}, \mathbf{7 . 9 0}$. Found: C, $74.41 ; \mathrm{H}, \mathbf{8 . 0 2}$. HPLC analysis: $\mathbf{1 5 a} / \mathbf{1 5 b}$ $=94 / 6$; endo:exo $=99.8: 0.2$.

Uncatalyzed Reaction of Compound 7 and Cyclopentadiene. Chiral acrylate $7(0.120 \mathrm{~g}, 0.178 \mathrm{mmol})$ in $\mathrm{CH}_{2} \mathrm{Cl}_{2}$ $(2.0 \mathrm{~mL})$ was taken in a small vial and cooled to $0^{\circ} \mathrm{C}$. To the cold stirred solution was added cyclopentadiene $(0.45 \mathrm{~mL}, 0.36$ $\mathrm{g}, 5.46 \mathrm{mmol}$ ), and stirring was continued for $36 \mathrm{~h}$. Removal of solvent and purification gave compounds $15 \mathrm{a} / \mathbf{1 5 b}$ and exo isomers $(0.120 \mathrm{~g})$ in $92 \%$ yield. HPLC analysis: $\mathbf{1 5 a} / \mathbf{1 5 b}=$ $32 / 68$; endo:exo $=79: 21$.

$\mathrm{BF}_{3} \cdot \mathrm{OEt}_{2}$-Catalyzed Reaction of Acrylate 10 with $\mathbf{C y}$ clopentadiene. Chiral acrylate $10(0.021 \mathrm{~g}, 0.03 \mathrm{mmol})$, MS $4 \mathrm{~A}(50 \mathrm{mg})$, and $\mathrm{CH}_{2} \mathrm{Cl}_{2}(2.5 \mathrm{~mL})$ were taken in a $100 \mathrm{~mL}$, round bottom flask, cooled to $-40^{\circ} \mathrm{C}$, and $\mathrm{BF}_{3} \cdot \mathrm{OEt}_{2}(0.038 \mathrm{~mL}$, $0.044 \mathrm{~g}, 0.309 \mathrm{mmol}$ ) was added followed by the slow addition of cyclopentadiene $(0.1 \mathrm{~mL}, 0.08 \mathrm{~g}, 1.21 \mathrm{mmol})$ over a period of $5 \mathrm{~min}$. After completion of the reaction ( $8 \mathrm{~h}$ ), it was worked up as mentioned above and purification of the resulting crude product gave compounds $16 \mathrm{a} / 16 \mathrm{~b}(0.0216 \mathrm{~g}, 93 \%)$ as a colorless solid: ${ }^{1} \mathrm{H}$ NMR ( $\left.\mathrm{CDCl}_{3}, 200 \mathrm{MHz}\right) 16 \mathrm{a}, \delta 8.15$ (d, $2 \mathrm{H}, J=8.4$ $\mathrm{Hz}), 7.74-7.41(\mathrm{~m}, 7 \mathrm{H}), 5.92(\mathrm{dd}, 1 \mathrm{H}, J=5.6$ and $2.8 \mathrm{~Hz}$ ), $5.84(\mathrm{dd}, 1 \mathrm{H}, J=5.6$ and $2.7 \mathrm{~Hz}), 5.21(\mathrm{~d}, 1 \mathrm{H}, J=2.3 \mathrm{~Hz})$, $5.16(\mathrm{~s}, 1 \mathrm{H}), 4.50(\mathrm{br} \mathrm{m}, 1 \mathrm{H}), 3.62(\mathrm{~s}, 3 \mathrm{H}), 2.83-2.72(\mathrm{~m}, 2 \mathrm{H})$, 2.39-0.77 (br m, steroidal $\mathrm{CH}_{2}$ and $\mathrm{CH}$ ), 2.204 (s, $\left.3 \mathrm{H}, 16 \mathrm{~b}\right)$, $2.185(\mathrm{~s}, 3 \mathrm{H}, 16 \mathrm{a}), 0.98(\mathrm{~s}, 3 \mathrm{H}), 0.83(\mathrm{~d}, 3 \mathrm{H}, J=6.1 \mathrm{~Hz}), 0.77$ $(\mathrm{s}, 3 \mathrm{H})$. HPLC analysis: $16 \mathbf{a} / \mathbf{1 6 b}=82 / 18$; endo:exo $=98: 2$.

Uncatalyzed Reaction of Acrylate 10 with Cyclopentadiene. Chiral acrylate $10(0.021 \mathrm{~g}, 0.030 \mathrm{mmol})$ in $\mathrm{CH}_{2} \mathrm{Cl}_{2}$ $(2.0 \mathrm{~mL})$ was taken in a small vial and cooled to $0^{\circ} \mathrm{C}$. To the cold stirred solution was added cyclopentadiene $(0.12 \mathrm{~mL}, 0.1$ $\mathrm{g}, 1.51 \mathrm{mmol}$ ), and the solution was stirred for $48 \mathrm{~h}$. The product was purified by column chromatography on silica gel and gave cycloadducts $16 \mathrm{a} / \mathbf{1 6 b}(0.0162 \mathrm{~g}, 70 \%)$ as a colorless foam. HPLC analysis: $16 \mathbf{a} / \mathbf{1 6 b}=34.5 / 65.5$; endo:exo $=82$ : 18.

$\mathrm{BF}_{3}-\mathrm{OEt}_{2}$-Catalyzed Reaction of Acrylate 13 with $\mathrm{Cy}$ clopentadiene. Compound $13(0.045 \mathrm{~g}, 0.078 \mathrm{mmol})$ and $\mathrm{MS}$ $4 \mathrm{~A}(50 \mathrm{mg})$ in $\mathrm{CH}_{2} \mathrm{Cl}_{2}(3.0 \mathrm{~mL})$ were taken in a flask and cooled to $-40^{\circ} \mathrm{C}$. $\mathrm{BF}_{3} \cdot \mathrm{OEt}_{2}(0.08 \mathrm{~mL}, 0.092 \mathrm{~g}, 0.651 \mathrm{mmol})$ was added via a syringe and after $5 \mathrm{~min}$ cyclopentadiene $(0.09 \mathrm{~mL}, 0.072$ $\mathrm{g}, 1.09 \mathrm{mmol}$ ) was added slowly and the solution was stirred for $12 \mathrm{~h}$. The reaction was worked up and purified to afford products $17 \mathrm{a} / 17 \mathrm{~b}$ in $60 \%$ yield $(0.030 \mathrm{~g})$ : ${ }^{1} \mathrm{H} \mathrm{NMR}\left(\mathrm{CDCl}_{3}, 200\right.$ MHz) $\delta 6.19(\mathrm{~m}, 1 \mathrm{H}), 5.91(\mathrm{~m}, 1 \mathrm{H}), 5.09(\mathrm{br} \mathrm{m}, 1 \mathrm{H}), 4.91(\mathrm{br}$ $\mathrm{m}, 1 \mathrm{H}), 4.52(\mathrm{br} \mathrm{m}, 1 \mathrm{H}), 3.66(\mathrm{~s}, 3 \mathrm{H}), 3.19(\mathrm{br} \mathrm{s}, 1 \mathrm{H}), 2.91(\mathrm{br}$ $\mathrm{m}, 2 \mathrm{H}), 2.16(\mathrm{~s}, 3 \mathrm{H}), 2.09$ (d, $3 \mathrm{H}, J=2.2 \mathrm{~Hz}), 0.92(\mathrm{~s}, 3 \mathrm{H})$, 0.82 (d, $3 \mathrm{H}, J=6.6 \mathrm{~Hz}), 0.74(\mathrm{~s}, 3 \mathrm{H})$.

Uncatalyzed Reaction of Acrylate 13 and Cyclopentadiene. Chiral acrylate $13(0.013 \mathrm{~g}, 0.022 \mathrm{mmol})$ in $\mathrm{CH}_{2} \mathrm{Cl}_{2}$ $(0.8 \mathrm{~mL})$ was taken in a small vial and cooled to $0^{\circ} \mathrm{C}$. To the cold stirred solution was added cyclopentadiene $(0.1 \mathrm{~mL}, 0.08$ $\mathrm{g}, 1.2 \mathrm{mmol}$ ), and the solution was stirred for $48 \mathrm{~h}$. The product was purified by preparative TLC using $20 \%$ ethyl acetate/hexanes as the eluant and gave cycloadduct $17 \mathbf{a} / \mathbf{1 7 b}$ in $80 \%$ yield $(0.012 \mathrm{~g}):{ }^{1} \mathrm{H}$ NMR $\left(\mathrm{CDCl}_{3}, 200 \mathrm{MHz}\right) \delta 6.18(\mathrm{~m}$, $1 \mathrm{H}), 5.9(\mathrm{~m}, 1 \mathrm{H}), 5.02(\mathrm{br} \mathrm{m}, 1 \mathrm{H}), 4.9(\mathrm{br} \mathrm{m}, 1 \mathrm{H}), 4.53(\mathrm{br} \mathrm{m}$, $1 \mathrm{H}), 3.66$ (s, 3H), 3.19 (br s, 1H), 2.95 (br m, 2H), 2.37-0.73 (br m, steroidal $\mathrm{CH}_{2}$ and $\mathrm{CH}$ ), $2.15(\mathrm{~s}, 3 \mathrm{H}), 2.09(\mathrm{~s}, 3 \mathrm{H}), 0.91$ (s, $3 \mathrm{H}), 0.82$ (d, $3 \mathrm{H}, J=5.9 \mathrm{~Hz}$ ), $0.73(\mathrm{~s}, 3 \mathrm{H})$.

Removal of Cycloadducts from the Chiral Auxiliary via Iodolactonization. To a well-stirred biphasic solution of cycloadducts $15 \mathrm{a} / 15 \mathrm{~b}(0.088 \mathrm{~g}, 0.119 \mathrm{mmol}), \mathrm{KI}(0.12 \mathrm{~g}, 0.72$ $\mathrm{mmol}$ ), and sodium bicarbonate $(0.101 \mathrm{~g}, 1.2 \mathrm{mmol})$ in a mixture of $\mathrm{CH}_{2} \mathrm{Cl}_{2}(5.0 \mathrm{~mL})$ and water $(0.3 \mathrm{~mL})$ was added iodine $(0.60 \mathrm{~g}, 0.235 \mathrm{mmol})$ at $\mathrm{rt}$. After the reaction mixture was stirred for $2 \mathrm{~h}$ at room temperature the reaction was diluted with water. The products were extracted with methylene chloride and the organic layer was washed successively with water, aqueous sodium thiosulfate solution (until solution become colorless), water, and brine. Purification of the crude product by column chromatography yielded enantiomeric iodo lactones $18 \mathrm{a} / 18 \mathrm{~b}$ in $75 \%$ yield $(0.023 \mathrm{~g})$ as a colorless solid and alcohol 6 in $88 \%$ yield $(0.065 \mathrm{~g})$ as a colorless foam: ${ }^{1} \mathrm{H}$ $\mathrm{NMR}\left(\mathrm{CDCl}_{3}, 90 \mathrm{MHz}\right) \delta 5.139(\mathrm{~d}, 1 \mathrm{H}, J=3.86 \mathrm{~Hz}$ ), 3.91 (d, $1 \mathrm{H}, J=3.87 \mathrm{~Hz}$ ), $3.22(\mathrm{~m}, 1 \mathrm{H}), 2.73-1.64$ (br m, 6H); IR (film) $2950,1782,1653,1542 \mathrm{~cm}^{-1} ;[\alpha]^{23}{ }_{\mathrm{D}}=+84.9^{\circ}\left(\mathrm{c} 1.85, \mathrm{CHCl}_{3}\right)$.

Acknowledgment. We gratefully acknowledge the support of this research by the Department of Science and Technology (Grant No. SP/S1/G09/91). The UGC is thanked for the award of a fellowship to P.M. The Sophisticated Instruments Facility at IISc is thanked for recording high field ${ }^{1} \mathrm{H}-\mathrm{NMR}$ and ${ }^{13} \mathrm{C}-\mathrm{NMR}$ spectra.

Supplementary Material Available: Complete experimental details for all reactions and ${ }^{1} \mathrm{H}$ - and ${ }^{13} \mathrm{C}-\mathrm{NMR}$ spectra for new compounds described in the Experimental Section (41 pages). This material is contained in libraries on microfiche, immediately follows this article in the microfilm version of the journal, and can be ordered from the ACS; see any current masthead page for ordering information.

J09409905 